\title{
EFFECTS OF TILLAGE SYSTEMS ON PHYSICAL PROPERTIES OF A COHESIVE YELLOW ARGISOL IN THE NORTHERN STATE OF ESPÍRITO SANTO, BRAZIL ${ }^{(1)}$
}

\author{
Valmir José Zuffo(2), Fabio Ribeiro Pires ${ }^{(3)}$, Robson Bonomo ${ }^{(3)}$, Edney Leandro da \\ Vitória $^{(3)}$, Ademar Celin Filho ${ }^{(4)}$ \& Eduardo Oliveira de Jesus Santos ${ }^{(4)}$
}

\begin{abstract}
SUMMARY
Tillage systems are a key element of the technology of crop production, both with a view to crop yield and from the perspective of soil conservation and sustainability of the production system. The aim of this paper was to evaluate the effects of five tillage systems on the physical properties of a cohesive Yellow Argisol. The experiment was installed in the field on January 21, 2011 and lasted 260 days, in an area previously used as pasture with Brachiaria grass without liming or fertilization, but irrigated by a low pressure spray system. The treatments, in five replications and in a randomized block design, consisted of: 1) disk plow (twice) + disk harrow + ridge-furrow tillage (raising a ridge along the planting row), 135 days after transplanting (DP + RID); 2) disk plow (twice) + disk harrow (DP no RID); 3) subsoiler (SB); 4) disk plow (twice) + disk harrow + scarification with three shanks along the plant row (DP + SPR); and 5) disk plow (twice) + disk harrow + scarification with three shanks in the total area (DP + STA). In all tillage systems, furrows were mechanically opened for the papaya plants. After the treatments, the mechanical resistance to penetration was determined, followed by soil moisture, mean weight diameter (MWD), geometric mean diameter (GMD), bulk density (BD), macroporosity (Ma), microporosity (Mi), and number of fruits per plant. There were differences in penetration resistance $(P R)$ between treatments. The subsoiler was more effective to decrease RP to a distance of 0.35 $\mathrm{m}$ from the plants, perpendicular to the plant row. The scarifier resulted in a lower PR than DP or SB, even at the depth of $0.40 \mathrm{~m}$, and it was more effective at greater distances perpendicular to the plant. All tillage systems induced a PR between 2.0 and 3.0 MPa at the depth with the highest concentration of papaya tree roots $(0-$
\end{abstract}

(1) Part of Master degree dissertation of the first author submitted to the Federal University of Espirito Santo - UFES. Received for publication on November 9, 2012 and approved on June 25, 2013.

(2) Agronomist, Master's degree in Tropical Agriculture, consultant in planning and agricultural production. R. Vitorino Bissoli, 811. CEP 29980-000 Pinheiros (ES), Brazil. E-mail: vjzuffo@hotmail.com

(3) Professor of Biological and Agricultural Sciences Departament, CEUNES/UFES. E-mail: pires.fr@gmail.com; robson.bonomo@gmail.com; vitoria.edney@gmail.com

(4) Undergraduate student, CEUNES/UFES. E-mail: ademar_celin@hotmail.com; eduardoliviera@hotmail.com 
$0.25 \mathrm{~m}$ ), improving the physical conditions to this depth. There was no statistical difference among the treatments for BD, Ma, Mi, MWD, and GMD at a depth of 0.20 m. The disk plow changed the physical properties of the soil most intensely to a depth of $0.20 \mathrm{~m}$. The use of scarification, reduced tillage with a forest subsoiler, or ridge-furrow tillage did not improve the physical properties in the rhizosphere. Reduced tillage with a forest subsoiler resulted in a lower number of fruits per plant than all other treatments, which did not differ from each other.

Index terms: Carica papaya, cohesive soils, coastal plains, soil management, soil physics.

\title{
RESUMO: EFEITOS DE PREPAROS DO SOLO NOS ATRIBUTOS FÍSICOS DE UM ARGISSOLO AMARELO COESO NO NORTE DO ESTADO DO ESPÍRITO SANTO
}

\begin{abstract}
Os sistemas de preparo do solo são parte fundamental da tecnologia de produção das culturas, tanto no sentido de rendimento das culturas quanto sob a perspectiva da conservação do solo e da sustentabilidade dos sistemas de produção. O objetivo deste artigo foi avaliar os efeitos de cinco sistemas de preparo do solo nos atributos físicos de um Argissolo Amarelo coeso. O experimento foi instalado em 21/01/2011 e conduzido em campo por 260 dias, em área anteriormente utilizada com pastagem de Brachiaria nunca corrigida ou fertilizada, irrigada por sistema de aspersão de baixa pressão. Os tratamentos, implantados em cinco repetições e em delineamento de blocos ao acaso, foram: grade aradora (duas vezes) + niveladora + camalhão sobre a linha, confeccionado 135 dias após o transplantio (GA com CAM); grade aradora (duas vezes) + niveladora (GA sem CAM); subsolador florestal (SF); grade aradora (duas vezes) + niveladora + escarificação com três hastes sobre a linha de plantio (GA + ELP); e grade aradora (duas vezes) + niveladora + escarificação com três hastes em área total $(G A+E A T)$. Todos os preparos receberam sulcamento mecanizado, visando ao plantio do mamoeiro. Após a implantação dos tratamentos, foi determinada a resistência mecânica à penetração (RP), acompanhada pela umidade do solo, pelo diâmetro médio ponderado (DMP), pelo diâmetro médio geométrico (DMG), pela densidade do solo (DS), pela macroporosidade (Ma), pela microporosidade (Mi) e pelo número de frutos por planta. Houve diferenças de resistência à penetração entre os tratamentos. O subsolador apresentou-se mais efetivo na diminuição da $R P$ até 0,35 $m$ de distância da planta, no sentido transversal à linha de plantio. O escarificador resultou em RP menor que GA ou $S F$, mesmo a $0,40 \mathrm{~m}$ de profundidade, e foi mais eficiente em maiores distâncias transversalmente à planta. Todos os preparos produziram RP entre 2,0 e 3,0 MPa na profundidade de maior concentração de raizes do mamoeiro (0-0,25 m), fornecendo boas condições físicas até essa profundidade. Não houve diferença estatística entre os tratamentos para DS, Ma, Mi, DMP e DMG, a 0,20 m de profundidade. A grade aradora alterou os atributos físicos do solo em maior intensidade nessa mesma profundidade. O uso da escarificação e do preparo reduzido com subsolador florestal ou a confecção do camalhão não melhorou o ambiente radicular, em relação a seus atributos físicos. $O$ uso de preparo reduzido com subsolador florestal produziu menor número de frutos por planta do que todos os outros tratamentos, os quais não diferiram entre si.
\end{abstract}

Termos de indexação: Carica papaya, solo coeso, tabuleiros costeiros, manejo do solo, física do solo.

\section{INTRODUCTION}

The northern region of the State of Espírito Santo has a relatively young agriculture, compared to the South and other states in the Southeastern region, from where most of the techniques and agricultural practices were introduced. Since the local environmental conditions are specific, these practices were not always successful, requiring modifications or abandonment. Soil tillage and management are no exception. In the case of papaya (Carica papaya L.), due to the restricted root growth (Costa et al., 2000), the sensitivity of the crop to soil hypoxia (Marler et al., 1994) and the characteristics of the soils, tillage is required to provide good aeration and rapid drainage.

There are few results of studies addressing the evaluation of an optimized method of soil tillage for papaya on the Coastal Plains (Costa et al., 2003). Older recommendations suggest seedling transplanting to systems of pits, grooves or ridges, with tillage consisting of plowing and one or two harrowings (Silva, 
1986). Other recommendations indicated plowing followed by one or two diskings, or mechanical mowing or plowing and one or two diskings, aside from the possibility of using no-tillage which consists of ridgefurrow tillage after growing corn or beans (Costa et al. 2003). In the presence of cohesive layers, tillage should be based on minimized heavy machine traffic and on systems that prioritize the use of shanks, scarifier or subsoilers (Cintra, 2005).

In practice, the variety of tillage forms is quite wide: plowing with heavy harrows or disc plows, leveling harrows, subsoilers (ripper or common), or scarifiers. In the management after transplanting, heavy disk harrows are used for weed control, modified leveling harrows to construct the ridge, mowers and even a furrow opener for surface smoothing. Producers only agree on the use of a furrow opener with shanks, after tillage, with the purpose of drawing the lines and loosening the soil to blend fertilizers. It is also worth mentioning how open producers are to test tillage and management systems that reduce soil tillage.

This study evaluated the effects of the five most commonly used tillage forms in the North of the State of Espírito Santo on the main soil physical properties of an irrigated soil of a papaya field (Formosa Tainung 01) on the Coastal Tableland, and proposed possibilities of using scarification as a complement to conventional tillage with a disk plow used by the fruit growers and reduced tillage with a subsoiler that reaches a depth of $1 \mathrm{~m}$ and eliminating ridge formation along the plant row.

\section{MATERIAL AND METHODS}

The experiment was installed in Boa Esperança, Espírito Santo (latitude $18^{\circ} 29^{\prime} 42,1^{\prime \prime}$, longitude $40^{\circ} 23^{\prime} 55,4^{\prime \prime}$, at $140 \mathrm{~m}$ asl) on a cohesive Yellow Argisol, flat terrain, after eight years of Brachiaria brizantha cv marandu cultivation, in an area never limed or fertilized before. According to Köppen's classification, the regional climate is Aw, with an average annual temperature of $22.6{ }^{\circ} \mathrm{C}$ and average annual rainfall of $1,022 \mathrm{~mm}$.

The experimental area was sampled with a steel corer (one sample per block) in two depth ranges (00.20 and $0.20-0.40 \mathrm{~m}$ ) which were analyzed for chemical properties and particle size (Table 1).

Moreover, the bulk density (BD) in the experimental area was determined, using the ring sampling method, as described by Blake \& Hartge (1986) (ring volume $142.5 \mathrm{~cm}^{3}$ ). The macroporosity - Ma (pore volume diameter $\geq 0.05 \mathrm{~mm}$ ) and microporosity - Mi (pore volume diameter $<0.05 \mathrm{~mm}$ ) was determined using the method proposed by Embrapa (1997) (Table 2), at the Laboratory of soil physics CEUNES/UFES in São Mateus - ES. One sample per block was collected from three depth ranges (0-0.20, 0.20-0.40 and 0.40-0.60 m).
The aggregate stability was determined using the method of Kemper \& Chepil (1965), using: $4.7 \mathrm{~mm}$ passing sieves, and 2.00, 1.00, 0.500 and $0.250 \mathrm{~mm}$ retention sieves. The retained fractions were shaken

Table 1. Chemical and particle size analyses of soil before installing the experiment

\begin{tabular}{|c|c|c|}
\hline \multirow{2}{*}{ Attribute } & \multicolumn{2}{|c|}{ Soil layer $(m)$} \\
\hline & $0-0.20$ & $0.20-0.40$ \\
\hline$P\left(\mathrm{mg} \mathrm{dm}^{-3}\right)^{(1)}$ & 1.6 & 1.0 \\
\hline P-resin $\left(\mathrm{mg} \mathrm{dm}{ }^{-3}\right)$ & 1.0 & 1.0 \\
\hline $\mathrm{K}\left(\mathrm{mg} \mathrm{dm}^{-3}\right)^{(1)}$ & 45.6 & 29.2 \\
\hline $\left.\mathrm{S}(\mathrm{mg} \mathrm{dm})^{-3}\right)^{(2)}$ & 3.8 & 4.8 \\
\hline $\mathrm{Ca}^{2+}\left(\mathrm{cmol}_{\mathrm{c}} \mathrm{dm}^{-3}\right)^{(3)}$ & 1.9 & 1.7 \\
\hline $\mathrm{Mg}^{2+}\left(\mathrm{cmol}_{\mathrm{c}} \mathrm{dm}^{-3}\right)^{(3)}$ & 0.3 & 0.2 \\
\hline $\mathrm{Al}^{3+}\left(\mathrm{cmol}_{\mathrm{c}} \mathrm{dm}^{-3}\right)^{(3)}$ & 0.0 & 0.0 \\
\hline $\mathrm{H}+\mathrm{Al}\left(\mathrm{cmol}_{\mathrm{c}} \mathrm{dm}^{-3}\right)^{(4)}$ & 1.6 & 1.6 \\
\hline $\mathrm{pH}\left(\mathrm{H}_{2} \mathrm{O}\right) 1: 2.5$ & 6.3 & 6.1 \\
\hline $\mathrm{OM}\left(\mathrm{dag} \mathrm{dm}^{-3}\right)^{(5)}$ & 2.4 & 1.6 \\
\hline $\left.\mathrm{Fe}(\mathrm{mg} \mathrm{dm})^{-3}\right)^{(1)}$ & 62.2 & 103.8 \\
\hline $\left.\mathrm{Zn}(\mathrm{mg} \mathrm{dm})^{-3}\right)^{(1)}$ & 0.4 & 0.3 \\
\hline $\left.\mathrm{Cu}(\mathrm{mg} \mathrm{dm})^{-3}\right)^{(1)}$ & 0.2 & 0.1 \\
\hline $\operatorname{Mn}\left(m g \mathrm{dm}^{-3}\right)^{(1)}$ & 17.4 & 8.4 \\
\hline $\left.\mathrm{B}(\mathrm{mg} \mathrm{dm})^{-3}\right)^{(6)}$ & 0.28 & 0.30 \\
\hline $\left.\mathrm{Na}(\mathrm{mg} \mathrm{dm})^{-3}\right)^{(1)}$ & 21.0 & 14.8 \\
\hline $\mathrm{Cl}\left(\mathrm{mg} \mathrm{dm}^{-3}\right)^{(7)}$ & 32.5 & 37.6 \\
\hline Sum of bases $\left(\mathrm{cmol}_{c} \mathrm{dm}^{-3}\right)$ & 2.5 & 2.0 \\
\hline Effective CEC $\left(\mathrm{cmol}_{\mathrm{c}} \mathrm{dm}^{-3}\right)$ & 2.5 & 2.0 \\
\hline CEC pH $7\left(\mathrm{cmol}_{\mathrm{c}} \mathrm{dm}^{-3}\right)$ & 4.2 & 3.6 \\
\hline Coarse sand $\left(\mathrm{g} \mathrm{kg}^{-1}\right)^{(8))}$ & 596 & 459 \\
\hline Fine sand $\left(\mathrm{g} \mathrm{kg}^{-1}\right)^{(8)}$ & 143 & 168 \\
\hline $\operatorname{Silt}\left(\mathrm{g} \mathrm{kg}^{-1}\right)^{(8)}$ & 106 & 121 \\
\hline Clay $\left(\mathrm{g} \mathrm{kg}^{-1}\right)^{(9)}$ & 156 & 252 \\
\hline
\end{tabular}

(1) Extracted by $\mathrm{HCl} 0.05 \mathrm{~mol} \mathrm{~L}^{-1}+\mathrm{H}_{2} \mathrm{SO}_{4} 0.025 \mathrm{~mol} \mathrm{~L}^{-1}$; (2) Extraction by $\mathrm{Ca}\left(\mathrm{H}_{2} \mathrm{PO}_{4}\right)_{2} 0.01 \mathrm{~mol} \mathrm{~L}^{-1}$; (3) Extraction by KCl $1 \mathrm{~mol} \mathrm{~L}^{-1}$; (4) SMP buffer solution; (5) Oxidation by $\mathrm{NaCr}_{2} \mathrm{O}_{7} 4 \mathrm{~mol} \mathrm{~L}-1+\mathrm{H}_{2} \mathrm{SO}_{4} 10 \mathrm{~mol} \mathrm{~L}{ }^{-1}$; (6) Extraction by $\mathrm{BaCl}_{2} .2 \mathrm{H}_{2} \mathrm{O} 0.125 \%$; ${ }^{(7)}$ Extraction by $\mathrm{H}_{2} \mathrm{O} 1: 5 ;{ }^{(8)}$ Embrapa (1997); ${ }^{9}$ Densimeter method.

Table 2. Bulk density (Bd), macroporosity (Ma), microporosity (Mi), total porosity (TP), mean weight diameter (MWD) and geometric mean diameter (GMD) of the experimental area prior to the experiment

\begin{tabular}{lccc}
\hline \multirow{2}{*}{ Attribute } & \multicolumn{3}{c}{ Soil layer (m) } \\
\cline { 2 - 4 } & $\mathbf{0 - 0 . 2 0}$ & $\mathbf{0 . 2 0 - 0 . 4 0}$ & $\mathbf{0 . 4 0 - 0 . 6 0}$ \\
\hline $\mathrm{BD}\left(\mathrm{g} \mathrm{cm}^{-3}\right)$ & $1.60 \pm 0.04$ & $1.65 \pm 0.04$ & $1.68 \pm 0.03$ \\
$\mathrm{Ma}\left(\mathrm{m}^{3} \mathrm{~m}^{-3}\right)$ & $0.17 \pm 0.02$ & $0.13 \pm 0.01$ & $0.12 \pm 0.01$ \\
$\mathrm{Mi}\left(\mathrm{m}^{3} \mathrm{~m}^{-3}\right)$ & $0.18 \pm 0.01$ & $0.21 \pm 0.01$ & $0.22 \pm 0.01$ \\
$\mathrm{TP}\left(\mathrm{m}^{3} \mathrm{~m}^{-3}\right)$ & $0.35 \pm 0.02$ & $0.34 \pm 0.02$ & $0.34 \pm 0.01$ \\
$\mathrm{MWD}(\mathrm{mm})$ & $3.34 \pm 0.01$ & $3.25 \pm 0.03$ & $2.71 \pm 0.19$ \\
$\mathrm{GMD}(\mathrm{mm})$ & $3.31 \pm 0.02$ & $3.11 \pm 0.07$ & $2.26 \pm 0.23$ \\
\hline
\end{tabular}


in a wet-sieve shaker (Yoder, 1936), stroke length $2.0 \mathrm{~cm}$, rest $4 \mathrm{~min}$, shaking for $4 \mathrm{~min}$, and rotation at $35 \mathrm{rpm}$. The mean weight diameter (MWD) and geometric mean diameter (GMD) were calculated according to the formulas proposed by Kemper \& Rosenau (1986) (Table 2). One sample per block was taken from three depth ranges $(0-0.20,0.20-0.40$ and $0.40-0.60 \mathrm{~m}$ ) with a mattock, with minimal breaking of the clods and packed in $50 \mathrm{~L}$ plastic bags for air drying in the laboratory.

Resistance to penetration (RP) was also determined prior to the experiment by sampling at six points per block, using an impact penetrometer (mass $4.0 \mathrm{kgf}$; rod diameter $9.0 \mathrm{~mm}$; tip diameter $12.83 \mathrm{~mm}$; angle $30^{\circ}$ ) according to the method of Stolf et al. (1983). The data of the number of impacts were transformed in pressure units $(\mathrm{MPa})$, according to the method described by Stolf (1991). At the same sampling points, moisture was determined by the gravimetric method (Embrapa, 1997) (Table 3).

The experiment was arranged in a randomized block design with five treatments and five replications. The plots consisted of four tree rows with eight papaya plants (a total of 32 trees) spaced $3.8 \mathrm{x}$ $2.1 \mathrm{~m}\left(1,253\right.$ plants ha- $\left.{ }^{-1}\right)$. The 2 central rows and 12 central plants (six per row) were evaluated. The plots were not adjacent but separated by $7.0 \mathrm{~m}$ in one and $5.0 \mathrm{~m}$ in the other direction, to ensure space for machinery movement.

The treatments were carried out from December 01 to 07,2010 , consisting of: 1 ) disk plow (twice) + disk harrow + ridge raised along the plant row, 135 after transplanting (DP + RID); 2) disk plow (twice) + disk harrow (DP no RID); 3) forest subsoiler (FS); 4) disk plow (twice) + disk plow (twice) + disk harrow + scarification with three shanks spaced $0.30 \mathrm{~m}$ apart, the central one above the plant row (DP + SPR); and 5) disk plow (twice) + disk plow (twice) + disk harrow + scarification with three shanks spaced laterally by $0.30 \mathrm{~m}$ in total area (DP + STA). The average depth of plowing reached $0.25 \mathrm{~m}$, scarification $0.40 \mathrm{~m}$, and subsoiling $0.70 \mathrm{~m}$.

All treatment areas were furrowed before transplanting with a furrow opener and the furrows were not undone throughout the experiment. The planting was done using loosened soil from within the furrow for fertilizer blending and seedling planting, taken from the furrow, and mixed with fertilizers.

Table 3. Soil resistance to penetration (RP) and soil moisture prior to the experiment

\begin{tabular}{lcccc}
\hline \multirow{2}{*}{ Attribute } & \multicolumn{4}{c}{ Depth range (m) } \\
\cline { 2 - 5 } & $\mathbf{0 - 0 . 1 0}$ & $\mathbf{0 . 1 0 - 0 . 2 0}$ & $\mathbf{0 . 2 0 - 0 . 3 0}$ & $\mathbf{0 . 3 0 - 0 . 4 0}$ \\
\hline $\mathrm{RP}(\mathrm{MPa})$ & 2.24 & 4.90 & 4.97 & 5.84 \\
Moisture (g $\left.100 \mathrm{~g}^{-1}\right)$ & 4.80 & 4.80 & 6.20 & 6.20 \\
\hline
\end{tabular}

The ridge along the plant row (treatment DP + RID) was formed 135 days after transplanting. Therefore, there were plots with four or five treatments.

The machines and implements used in the study were: a) Machines: tractor $180 \mathrm{hp}$ for forest subsoiler; tractor $140 \mathrm{hp}$ for the heavy disk harrow; tractor 75 $\mathrm{hp}$ for the scarifier, heavy disk harrow, leveling harrow and a furrow opener; b) Attachments: offset disk harrow with 14 disc blades, diameter 32"; a forest subsoiler with winged tip and curved shaft, 3 ripper shanks, off set harrow with 24 flat discs, diameter 24 ", furrow opener with shanks.

Three seedlings of the genotype Tainung $01 \mathrm{~F}_{1}$ papaya hybrid were transplanted to each planting hole, with subsequent sexing (60-75 days after transplanting), selecting one hermaphrodite or one female plant (when there were three female plants per hole). The seedlings were grown in $60 \mathrm{~mL}$ tubes (height $13 \mathrm{~cm}$ ) filled with a commercial substrate. The seedlings were planted in the field on 01/21/2011.

Fertilization during the experimental period consisted of $128 \mathrm{~kg} \mathrm{ha}^{-1} \mathrm{~N}, 269 \mathrm{~kg} \mathrm{ha}^{-1} \mathrm{P}_{2} \mathrm{O}_{5}, 396 \mathrm{~kg} \mathrm{ha}^{-1} \mathrm{~K}_{2} \mathrm{O}$, $174 \mathrm{~kg} \mathrm{ha}^{-1} \mathrm{Ca}, 5.6 \mathrm{~kg} \mathrm{ha}^{-1} \mathrm{Mg}$, and $107 \mathrm{~kg} \mathrm{ha}^{-1} \mathrm{~S}$.

Irrigation was performed with a low-pressure sprinkler, spraying water at a pressure of about $200 \mathrm{kPa}$ and at a flow rate of approximately $1.8 \mathrm{~m}^{3} \mathrm{~h}^{-1}$. Two tensiometer batteries were installed at depths of 0.15 and $0.30 \mathrm{~m}$ and irrigation was performed whenever the tension in the device closest to the surface indicated values above $25 \mathrm{kPa}$.

All other cultural practices were performed according to the techniques of papaya production described by Martins \& Costa (2003). Weeds were controlled as follows: a) along the plant row, in all treatments, with weeding $(2 \mathrm{x})$ and paraquat herbicide applications (2x); and b) between rows, with one offset disk harrowing (cutting width $1.7 \mathrm{~m}$ ), performed before sampling for soil analyses, and two uncoordinated passings after that (except for treatment 3 which was mowed 3x).

Eighty days after the treatments, resistance to penetration was evaluated with an electronic penetrograph, Mark Falker, model penetroLOG ${ }^{\circledR}$ PLG 1020 , at a working speed of maximum penetration of $30 \mathrm{~mm} \mathrm{~s}^{-1}$, cone type 2 (diameter $12.83 \mathrm{~mm}$, base area $1.3 \mathrm{~cm}^{2}$, angle $30^{\circ}$, max. cone index $7,700 \mathrm{kPa}$ ), according to ASAE S313.3 (ASAE, 1999). Fifteen replications per treatment (three replications per plot) were taken in two directions in relation to the plant row (longitudinal and perpendicular), at five distances from the plant rows in each direction $(0.25,0.35,0.50$, 0.65 , and $0.75 \mathrm{~m}$ ). When measuring the resistance to penetration, three samples per plot were collected at a distance of $0.25 \mathrm{~m}$ from the papaya trees in the perpendicular direction for moisture analysis, determined by the gravimetric method (Embrapa, 1997). 
Measurements of soil bulk density, macroporosity and microporosity were performed 86 days after treatment application by collecting one sample per plot at three distances from the papaya trees $(0.20$, 0.40 and $0.60 \mathrm{~m})$ and from two depths $(0.20$ and $0.40 \mathrm{~m}$ ), by the same method as described for the characterization of the area, but using volumetric rings $\left(92.5 \mathrm{~cm}^{3}\right)$.

To determine the mean particle diameter and geometric mean diameter, 135 days after treatment application, one sample per plot was collected at a distance of $0.25 \mathrm{~m}$ from the papaya trees and from two depths $(0.20$ and $0.40 \mathrm{~m})$. These samples were taken with a mattock, with minimal breaking of the clods and packed in 50-L plastic bags for air drying in the laboratory.

To estimate the yield, the number of fruits per plant was counted 260 days after transplanting.

The statistical treatment of the data consisted of calculating the mean standard error for soil penetration resistance and moisture. The remaining data were subjected to analysis of variance and Tukey's test at $5 \%$ probability, to compare means using the GENES program (Cruz, 2006).

\section{RESULTS AND DISCUSSION}

Measurements of soil resistance to penetration 80 days after treatment application, performed with the penetrometer, were plotted in graphs where the horizontal bars represent the standard error of the mean (Figures 1 and 2). The water contents of the two layers help correlate the penetration resistance to soil moisture (Table 4), including other studies, since they are strongly dependent (Dexter et al., 2007).

In the perpendicular direction PD to plant rows (Figure 1), the results show variations of penetration resistance (PR) in the order of $0.2-3.0 \mathrm{MPa}$, which are moderate values that are within the interval considered adequate (Grant \& Lanfond, 1993; Imhoff et al., 2000; Merotto Junior \& Mundstock, 1999; Hamza \& Anderson, 2005). This can be a result of mobilizing action of the treatments (with exception of $\mathrm{SB}$ ), because even those with scarification, along the plant row or in the total area, were harrowed. In all graphics it was also observed that differences between tillage systems appear at depth $0.10 \mathrm{~m}$, indicating the ease of tillage in the major part of horizon A (approximate thickness of $0.23 \mathrm{~m}$ in this soil). In general, at distances of 0.25 and $0.35 \mathrm{~m}$, the PR values in the FS treatment were lower, mainly at depths below $0.25 \mathrm{~m}$. The action of FS was more effective at a distance of up to $0.35 \mathrm{~m}$ from the plant, and may even induce higher $\mathrm{PR}$ values than the scarifier in layers below $0.20 \mathrm{~m}$ (Figure 1d,e).

The PR values in the harrowed soil were, in general, higher than those of other treatments at depths below
$0.20 \mathrm{~m}$, evidencing the surface action of the harrowing. In general, at distances of 0.50 and $0.65 \mathrm{~m}$, the treatment effects tended to be equal. At distances of 0.65 and $0.75 \mathrm{~m}$, the PR of treatment DP + STA were lower than of the other treatments, showing the horizontal uniformity of tillage resulting from the use of scarification of the total area, in contrast to the subsoiler. Until 0.25 and $0.35 \mathrm{~m}$ away the $\mathrm{PR}$ is lower, mainly at depths below $0.25 \mathrm{~m}$, for the treatments SB and DP + SPR indicating that the loosened soil within the groove for fertilizer blending and seedling planting, traditionally used for papaya planting, is affected by soil tillage, although locally, both in the vertical and horizontal direction.

Considering the longitudinal direction (LD) to the plant row (Figure 2), the PR values were generally slightly higher than in TD. The reason was that the planting furrow remained open throughout the experimental period, so that the measurements were performed in deeper layers in the soil profile, since the device measures from the first millimeters it touches to the maximum calibrated soil depth. A coherence in data was also observed, since the graphs, in terms of the distances (Figure 2a,b,c,d,e) have the same shape, showing the effect of tillage direction (in the same direction as the distances taken for measurements). The PR values in the treatment FS were around $0.2-0.5 \mathrm{MPa}$, differing from the other treatments, especially at depths above $0.25 \mathrm{~m}$. Again, this demonstrates that tillage with FS has a good effect in deeper layers, but to short distances only in the TD. The treatment DP + SPR resulted in intermediate $\mathrm{PR}$ values between $\mathrm{SB}$ and $\mathrm{DP}$ or $\mathrm{DP}+$ STA, at depths below $0.25 \mathrm{~m}$. This also demonstrates the effect of scarification on the plant row in terms of increasing PR more than SB, but less than DP or DP + STA. Moreover, the curves related to DP and DP + STA were similar in all graphs, at depths below 0.20 $\mathrm{m}$. Probably, this result was due to the fact that there is no perfect coincidence of scarification in the total area with the plant row.

Considering both sampling directions, the maximum values found to a depth of $0.25 \mathrm{~m}$, in the zone of highest concentration of papaya roots (Costa et al., 2000; Coelho et al., 2005), ranged from 2.0 to 3.0 $\mathrm{MPa}$, which lower than the values indicated by Campostrini \& Yamanishi (2001) (4.1 MPa) as restrictive for the physiology of papaya trees. When compared other studies, this interval is close to or below the maximum values proposed in the literature for other crops: 2.0 MPa (Senra et al., 2007); $2.5 \mathrm{MPa}$ (Unger \& Kaspar, 1994); 3.5 MPa (Tavares Filho et al., 2001); 1.5 to 3.0 MPa (Grant \& Lanfond, 1993); 2.0 to $3.0 \mathrm{MPa}$ (Imhoff et al., 2000), 1.0 to $3.5 \mathrm{MPa}$ (Merotto Junior \& Mundstock, 1999); and 2.5 to 3.0 MPa (Hamza \& Anderson, 2005).

The bulk density (BD) values found prior to the experiment (Table 2$), 1.60 \mathrm{~g} \mathrm{~cm}^{-3}(0-0.20 \mathrm{~m}$ deep), $1.65 \mathrm{~g} \mathrm{~cm}^{-3}\left(0.20-0.40 \mathrm{~m}\right.$ deep), and $1.68 \mathrm{~g} \mathrm{~cm}^{-3}(0.40-$ 


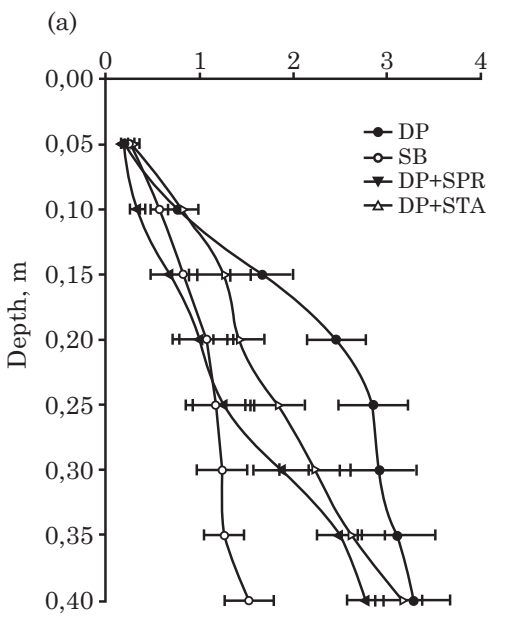

(b) $\quad \mathrm{RP}, \mathrm{MPa}$

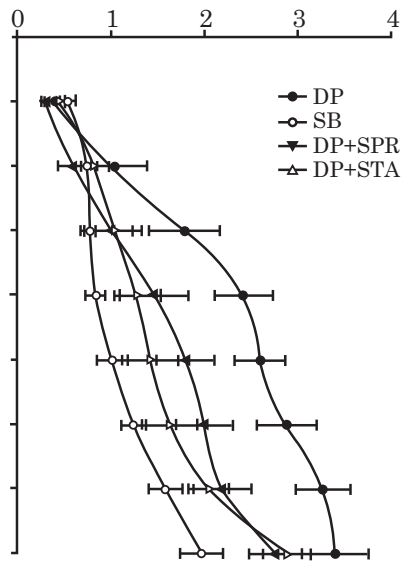

(c)

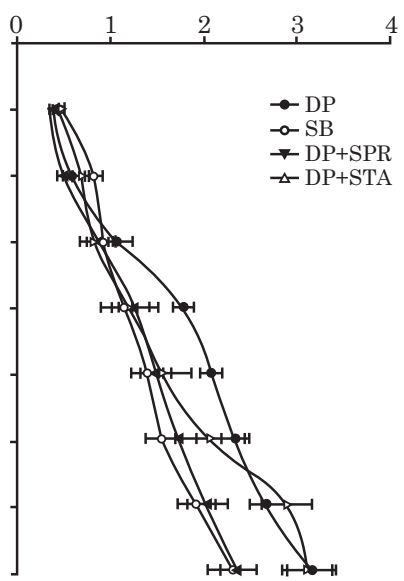

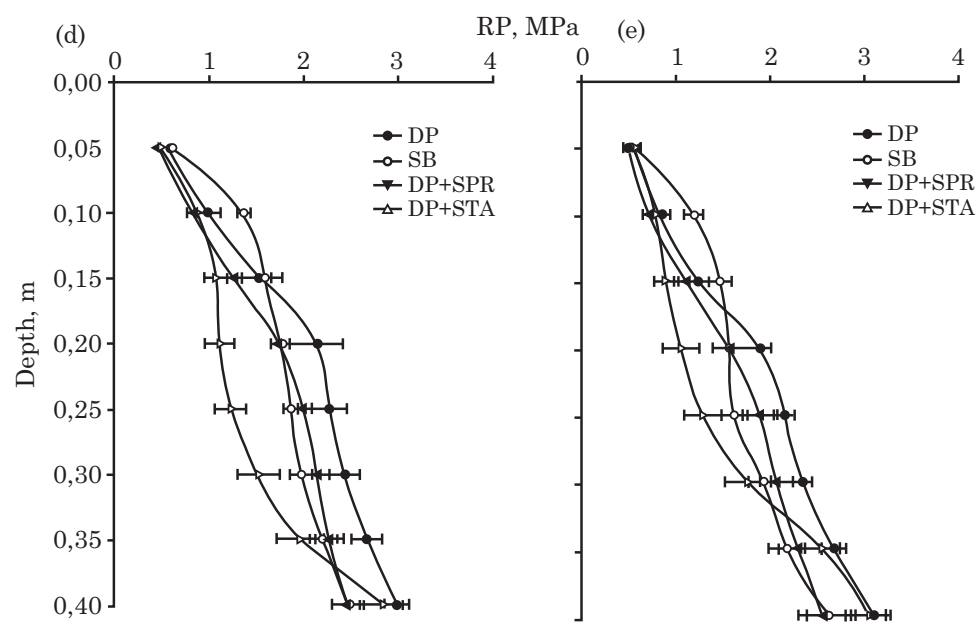

Figure 1. Soil resistance to penetration in the perpendicular direction to the plant row, at distances of 0.25 $\mathrm{m}(\mathrm{a}) ; 0.35 \mathrm{~m}$ (b); $0.50 \mathrm{~m}$ (c); $0.65 \mathrm{~m}$ (d); and $0.75 \mathrm{~m}$ (e); 80 days after soil tilling. Disk plow (DP); subsoiler (SB); disk harrow + scarification with shanks along the plant row (DP + SPR); disk harrow + scarification with rods in the total area (DP + STA).

Table 4. Soil moisture during measurements of resistance to penetration under penetrometer in four soil tillage forms

\begin{tabular}{lcr}
\hline \multirow{2}{*}{ Treatment } & \multicolumn{2}{c}{ Depth range (m) } \\
\cline { 2 - 3 } & \multicolumn{0}{c}{$\mathbf{0 - 0 . 2 0}$} & $\mathbf{0 . 2 0 - 0 . 4 0}$ \\
\cline { 2 - 3 } & \multicolumn{2}{c}{ g $100 \mathrm{~g}^{-1}$} \\
DP & $12.9 \pm 0.3$ & $12.4 \pm 0.3$ \\
SB & $12.7 \pm 0.7$ & $13.5 \pm 0.4$ \\
DP + SPR & $12.8 \pm 0.5$ & $13.3 \pm 0.5$ \\
DP + STA & $12.7 \pm 0.5$ & $10.8 \pm 0.5$ \\
\hline
\end{tabular}

$0.60 \mathrm{~m}$ deep) exceeded the values found by Coelho et al. (2005) in non-cohesive surface horizons (1.20 to $1.40 \mathrm{~g} \mathrm{~cm}^{-3}$ ), but were similar in the cohesive horizons $\left(1.50\right.$ to $\left.1.80 \mathrm{~g} \mathrm{~cm}^{-3}\right)$. They were also higher than those found after installing the experiment (Table 5), i.e. all tillage systems reduced BD significantly.
The results for $\mathrm{BD}$ show little variation between samples, expressed by the coefficient of variation (CV), from 3 to $9 \%$ (Table 5). Melo Filho et al. (2006) found a low CV in cohesive Yellow Argisol on tablelands, concluding that three replications are needed to represent the average of this property in the profile. These values range from 1.22 to $1.52 \mathrm{~g} \mathrm{~cm}^{-3}$ at a depth of $0.20 \mathrm{~m}$ and from 1.43 to $1.59 \mathrm{~g} \mathrm{~cm}^{-3}$ at $0.40 \mathrm{~m}$. These values are slightly lower than those found by Carvalho et al. (2004), which ranged from 1.51 to 1.67 $\mathrm{g} \mathrm{cm}^{-3}$, for the same soil type under tillage treatments.

The statistical comparison showed no differences between treatments, except at a depth of $0.40 \mathrm{~m}$ and at a perpendicular distance of $0.60 \mathrm{~m}$, where $\mathrm{BD}$ was higher in the DP treatment than in the DP + SPR. In a study by Carvalho et al. (2004), where tillage systems for papaya cultivation were tested with or without subsoiling, the effect of subsoiling to decrease BD was not clear. Similar results were found by Minatel et al. (2006) and Cortez et al. (2011), as well as by the review of 35 studies on tillage systems 

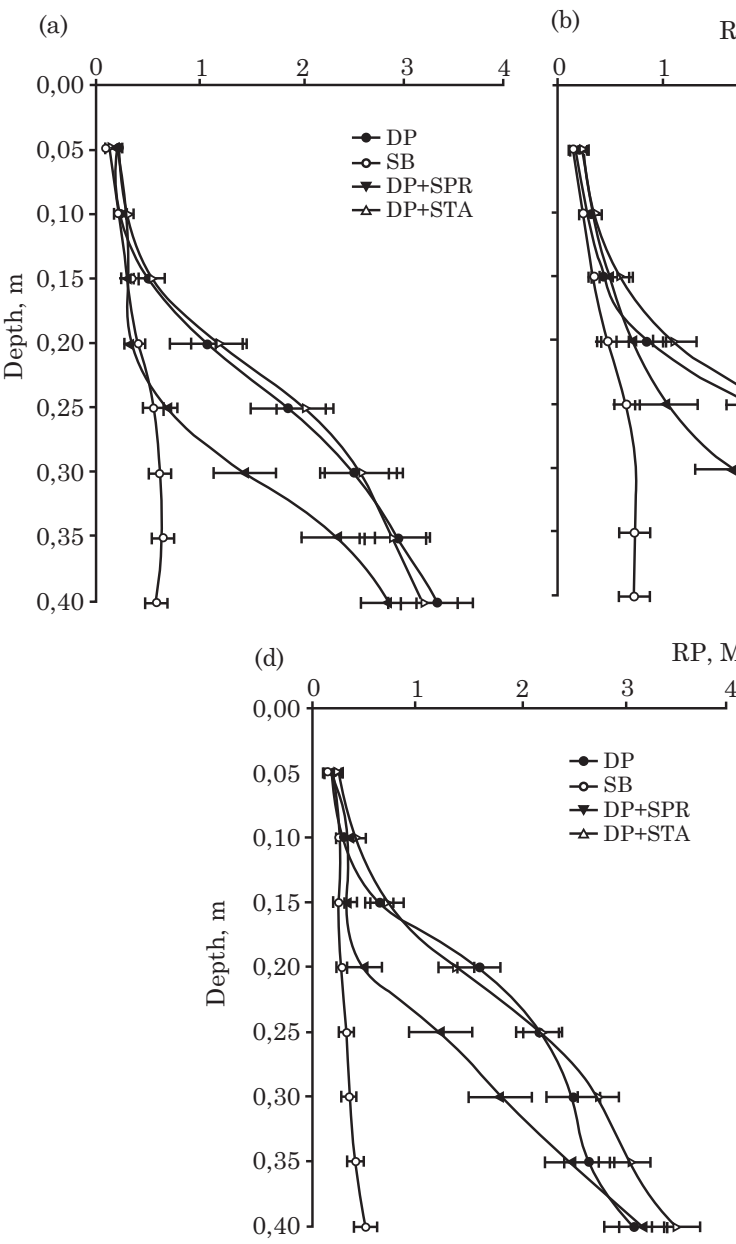

(b)

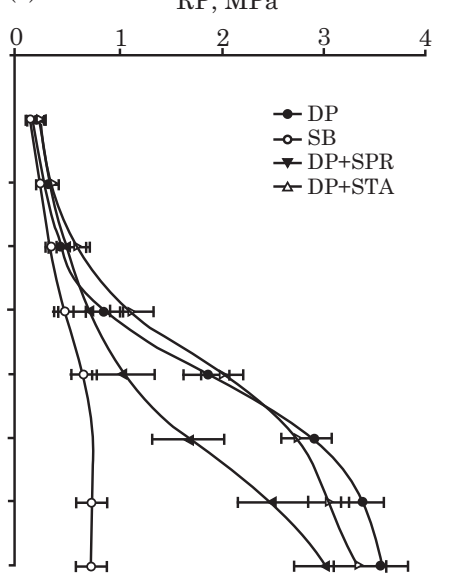

(c)

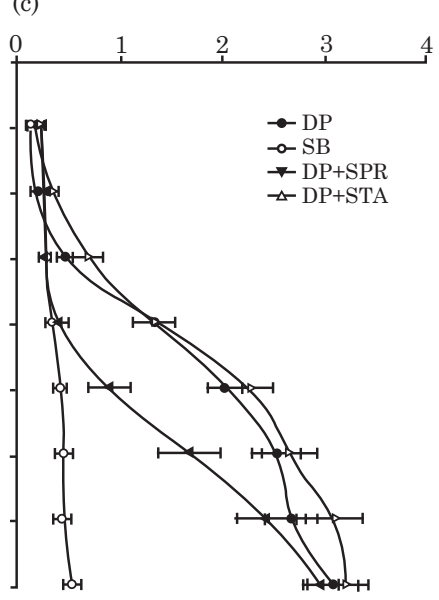

$\operatorname{MPa}(\mathrm{e})$



Figure 2. Soil resistance to penetration, in the longitudinal direction to the plant row, at distances of $0.25 \mathrm{~m}$ (a); $0.35 \mathrm{~m}$ (b); $0.50 \mathrm{~m}$ (c); $0.65 \mathrm{~m}$ (d); and $0.75 \mathrm{~m}$ (e); 80 days after soil tilling. Disk harrow (DP); forest subsoiler (SB); disk harrow + scarification with rods along the plant row (DP + SPR); disk harrow + scarification with rods in the total area $(\mathrm{DP}+\mathrm{STA})$.

carried out by Alvarez \& Steinbach (2009). The literature is rather contradictory with regard to the relationship between tillage or management systems and BD. The studies by Santos (1992), Costa et al. (2009), and Mazurana et al. (2011) mention different tillage systems reducing BD. Adekiya et al. (2011) found lower densities in the treatment plowing + two diskings than after hand weeding (without tillage), furrowing with hoe or planting along the ridge raised with a hoe.

There are considerable variations in $\mathrm{BD}$ in the cohesive soils of the coastal plains. Cintra (2005) found densities of $1.57 \mathrm{~g} \mathrm{~cm}^{-3}$, at a depth of $0.20 \mathrm{~m}$, in a dystrophic Yellow Argisol and of $1.68 \mathrm{~g} \mathrm{~cm}^{-3}$ in an alic Yellow Argisol; at a depth of $0.40 \mathrm{~m}$, bulk density was 1.61 and $1.70 \mathrm{~g} \mathrm{~cm}^{-3}$, respectively. In the study by Melo Filho et al. (2006), densities were determined to a depth of $0.45 \mathrm{~m}$, with values from 1.64 to $1.73 \mathrm{~g} \mathrm{~cm}^{-3}$ in a cohesive Yellow Argisol on tablelands. Paiva et al. (2000) report $\mathrm{BD}$ values of 1.57 and $1.59 \mathrm{~g} \mathrm{~cm}^{-3}$ in the layers 0-0.18 and 0.18-0.46 m, respectively, in a Yellow Argisol on the tablelands. Santana et al. (2006) found, in a Yellow Argisol on tablelands, BD of 1.43, $1.71,1.56$ and $1.65 \mathrm{~g} \mathrm{~cm}^{-3}$ in the layers $0-0.09,0.09$ $0.38,0.72-1.20$ and $0.38-0.72 \mathrm{~m}$, respectively. Brandão et al. (2011) found, in a cohesive Yellow Argisol after plowing or subsoiling, the following BD values: 1.36$1.81 \mathrm{~g} \mathrm{~cm}^{-3}$ (layer $0-0.20 \mathrm{~m}$ ), $1.68-1.81 \mathrm{~g} \mathrm{~cm}^{-3}$ (layer $0.20-0.40 \mathrm{~m}$ ), and $1.72-1.83 \mathrm{~g} \mathrm{~cm}^{-3}$ (layer 0.40-0.60 m).

The macroporosity ( $\mathrm{Ma}$ ) values at a depth of $0.20 \mathrm{~m}$ ranged from 0.219 to $0.307 \mathrm{~m}^{3} \mathrm{~m}^{-3}$ and at $0.40 \mathrm{~m}$ from 0.175 to $0.193 \mathrm{~m}^{3} \mathrm{~m}^{-3}$ (Table 5). These values are within the limits considered appropriate for good plant growth, based on the reference values of Xu et al. (1992), while being close to, or slightly below the threshold indicated by Taylor \& Aschroft (1972), of $0.33 \mathrm{~m}^{3} \mathrm{~m}^{-3}$. When compared to the values prior to the treatments (Table 3), a significant increase was observed in this property in the $0-0.20 \mathrm{~m}$ layer (from around 0.170 to a range of $0.220-0.310 \mathrm{~m}^{3} \mathrm{~m}^{-3}$ ), reflecting the effect of preparations. In turn, the values in the $0.20-0.40 \mathrm{~m}$ layer hardly changed at all. Santana et al. (2006) found the following Ma values 
Table 5. Bulk density macroporosity and microporosity in four tillage systems, 86 days after installing the experiment

\begin{tabular}{|c|c|c|c|c|c|c|}
\hline \multirow{2}{*}{ Treatment } & \multicolumn{6}{|c|}{ Plant depths ${ }^{(1)}$ and distances ${ }^{(2)}$} \\
\hline & De20 Di20 & De20 Di40 & De20 Di60 & De40 Di20 & De40 Di40 & De40 Di60 \\
\hline & \multicolumn{6}{|c|}{ Bulk density $\left(\mathrm{g} \mathrm{cm}^{-3}\right)$} \\
\hline $\mathrm{DP}$ & $1.28 \mathrm{a}$ & $1.35 \mathrm{a}$ & $1.47 \mathrm{a}$ & $1.55 \mathrm{a}$ & $1.57 \mathrm{a}$ & $1.59 \mathrm{a}$ \\
\hline SB & $1.34 \mathrm{a}$ & $1.39 \mathrm{a}$ & $1.52 \mathrm{a}$ & $1.43 \mathrm{a}$ & $1.47 \mathrm{a}$ & $1.54 \mathrm{ab}$ \\
\hline $\mathrm{DP}+\mathrm{SPR}$ & $1.22 \mathrm{a}$ & $1.25 \mathrm{a}$ & $1.38 \mathrm{a}$ & $1.52 \mathrm{a}$ & $1.53 \mathrm{a}$ & $1.58 \mathrm{ab}$ \\
\hline $\mathrm{DP}+\mathrm{STA}$ & $1.36 \mathrm{a}$ & $1.39 \mathrm{a}$ & $1.41 \mathrm{a}$ & $1.56 \mathrm{a}$ & $1.48 \mathrm{a}$ & $1.50 \mathrm{~b}$ \\
\hline $\operatorname{Mean}^{(3)}$ & 1.30 & 1.35 & 1.44 & 1.51 & 1.51 & 1.55 \\
\hline \multirow[t]{2}{*}{$\mathrm{CV}(\%)$} & 7.34 & 6.48 & 7.50 & 9.14 & 7.50 & 3.03 \\
\hline & \multicolumn{6}{|c|}{ Macroporosity $\left(\mathrm{m}^{3} \mathrm{~m}^{-3}\right)$} \\
\hline $\mathrm{DP}$ & $0.3268 \mathrm{a}$ & $0.2871 \mathrm{a}$ & $0.1934 \mathrm{a}$ & $0.1535 \mathrm{a}$ & $0.1727 \mathrm{a}$ & $0.1721 \mathrm{a}$ \\
\hline SB & $0.3019 \mathrm{a}$ & $0.3075 \mathrm{a}$ & $0.1932 \mathrm{a}$ & $0.2237 \mathrm{a}$ & $0.2011 \mathrm{a}$ & $0.1818 \mathrm{a}$ \\
\hline $\mathrm{DP}+\mathrm{SPR}$ & $0.3126 \mathrm{a}$ & $0.3125 \mathrm{a}$ & $0.2443 \mathrm{a}$ & $0.1880 \mathrm{a}$ & $0.2119 \mathrm{a}$ & $0.1515 \mathrm{a}$ \\
\hline $\mathrm{DP}+\mathrm{STA}$ & $0.2882 \mathrm{a}$ & $0.2693 \mathrm{a}$ & $0.2469 \mathrm{a}$ & $0.1772 \mathrm{a}$ & $0.1870 \mathrm{a}$ & $0.1978 \mathrm{a}$ \\
\hline $\operatorname{Mean}^{(3)}$ & 0.3074 & 0.2941 & 0.2194 & 0.1856 & 0.1932 & 0.1758 \\
\hline \multirow[t]{2}{*}{$\mathrm{CV}(\%)$} & 8.93 & 16.16 & 16.30 & 45.57 & 29.28 & 18.91 \\
\hline & \multicolumn{6}{|c|}{ Microporosity $\left(\mathrm{m}^{3} \mathrm{~m}^{-3}\right)$} \\
\hline $\mathrm{DP}$ & $0.1497 \mathrm{a}$ & $0.1519 \mathrm{a}$ & $0.2101 \mathrm{a}$ & $0.2083 \mathrm{a}$ & $0.2017 \mathrm{a}$ & $0.1892 \mathrm{a}$ \\
\hline SB & $0.1363 \mathrm{a}$ & $0.1249 \mathrm{a}$ & $0.1894 \mathrm{a}$ & $0.1778 \mathrm{a}$ & $0.1909 \mathrm{a}$ & $0.1831 \mathrm{a}$ \\
\hline $\mathrm{DP}+\mathrm{SPR}$ & $0.1585 \mathrm{a}$ & $0.1602 \mathrm{a}$ & $0.1888 \mathrm{a}$ & $0.1980 \mathrm{a}$ & $0.1782 \mathrm{a}$ & $0.2173 \mathrm{a}$ \\
\hline $\mathrm{DP}+\mathrm{STA}$ & $0.1544 \mathrm{a}$ & $0.1690 \mathrm{a}$ & $0.1898 \mathrm{a}$ & $0.1950 \mathrm{a}$ & $0.1999 \mathrm{a}$ & $0.1879 \mathrm{a}$ \\
\hline Mean $^{(3)}$ & 0.1497 & 0.1515 & 0.1946 & 0.1948 & 0.1927 & 0.1944 \\
\hline $\mathrm{CV}(\%)$ & 11.43 & 18.18 & 17.50 & 24.90 & 14.82 & 16.76 \\
\hline
\end{tabular}

${ }^{(1)} \mathrm{De}=\operatorname{depth}(\mathrm{cm}) ;{ }^{(2)} \mathrm{Di}=$ distance from the plant $(\mathrm{cm})$ (perpendicular to the plant row); ${ }^{(3)}$ Means followed by the same letter do not differ by Tukey's test at $5 \%$.

in Yellow Argisol on tablelands, in the respective layers: $0.146 \mathrm{~m}^{3} \mathrm{~m}^{-3}(0-0.09 \mathrm{~m})$ and $0.062 \mathrm{~m}^{3} \mathrm{~m}^{-3}(0.09-0.38 \mathrm{~m})$.

The statistical analysis showed no difference in the Ma values between treatments (Table 5). A study by Carvalho et al. (2004) reported no apparent changes in Ma due to tillage systems under papaya cultivation. Studying mechanical treatments of bush management, subsoiling, or plant cover of a Red Argisol with $250 \mathrm{~g}$ $\mathrm{kg}^{-1}$ clay, Minatel et al. (2006) found no differences either in Ma in the comparison of these treatments.

The studies by Nacif (1994) and Santos (1992) detected increased total porosity with subsoiling in coastal plain soils. Rosa et al. (2011) stated a Ma increase from 7.2 to $13.1 \%$ at the depths 0.23 and $0.26 \mathrm{~m}$, respectively, by subsoiling. Bordin et al. (2008) observed increased macroporosity in a dystrophic Red Argisol scarified with seven curved shafts to a depth of $0.30 \mathrm{~m}$.

The studies by Costa et al. (2009) and Cortez et al . (2011) reported decreased total porosity by the use of scarifiers. Mazurana et al. (2011), investigating scarification in no tillage, by means of Ma analysis, found positive effects of scarification to a depth of 0.12 $\mathrm{m}$, which tend to be zero in the 0.20-0.30 m layer.

The effects of tillage systems on the porosity values may be less apparent; they are clearer with regard to the pore shape and distribution (Schaefer et al., 2001).
Prior to the experiment, the microporosity (Mi) values ranged from 0.180 to $0.220 \mathrm{~m}^{3} \mathrm{~m}^{-3}$. Santana et al. (2006) found higher values $\left(0.250-0.270 \mathrm{~m}^{3} \mathrm{~m}^{-3}\right)$ for a cohesive Yellow Argisol.

In a general comparison of Mi data before and after installing the experiment, little may be concluded about changes by tillage with regard to this property. In the depth range from 0 to $0.20 \mathrm{~m}$, there was a slight decrease up to a distance of $0.40 \mathrm{~m}$ and no change at a distance of $0.60 \mathrm{~m}$. In the depth range from 0.20 to $0.40 \mathrm{~m}$, there was no change. In general, higher coefficients of variation for this property were observed in the $0-0.40 \mathrm{~m}$ than in the $0-0.20 \mathrm{~m}$ layer.

The statistical comparison of means showed no difference between the tillage systems (Table 5). Araujo et al. (2004) pointed out that Mi is little influenced by the soil management. Ribeiro et al. (2007) compared soil managements with harrowing and combinations of mowing and plant covers for cashew grown in a dystrophic sandy gray Argisol. The treatments induced no statistical differences in $\mathrm{Mi}$.

Santos (1992) and Nacif (1994) compared tillage systems in a cohesive Yellow Argisol, focused on subsoiling, and concluded that the tillage systems decreased Mi. In a Haplumbrept, Costa et al. (2009) also found lower Mi after plowing or scarification, compared to no-tillage. 
The t-test for the MWD values before and after treatments (Tables 2 and 6) showed that, in spite of the intensity (scarifier or subsoiler) and number of operations (two heavy diskings and one leveling) in the treatments, no significant changes were induced with regard to this property. This shows that, from the point of view of soil aggregate stability and conservation, all treatments may be used for papaya and that the structural weakness of this soil is not significant, in spite of its sandy texture and the low organic matter content for this soil class detected to a depth of $0.20 \mathrm{~m}$. The period of pasture use may have been responsible for this good aggregation, which the period under tillage systems was not long enough to change. In the data obtained before the treatments, a small decrease in MWD (0-0.60 m) was also observed along the profile. The values found by Paiva et al. (2000) in coastal plain soils ranged from $1.23 \mathrm{~mm}$ (0-0.18 $\mathrm{m}$ deep) to $0.94 \mathrm{~mm}$ (0.18-0.46 $\mathrm{m}$ deep), lower than those found in this study, but also with a slight decrease in depth.

After the treatments, the MWD values ranged from 2.90 to $3.32 \mathrm{~mm}$ (Table 6 ). In the $0-0.20 \mathrm{~m}$ layer, the MWD did not differ in statistical terms between treatments. In the 0-0.40 m layer, the tillage effects were very similar, despite statistical differences. The MWD was lower in SB than DP + STA, showing that subsoiling can reduce the MWD more than scarification, perhaps because of the high energy applied to the soil by the equipment. Contrary to the findings, Fontes et al. (2007) tested eight tillage systems in a cambic Red-Yellow Argisol. The treatments which promoted the highest mean MWD values $(0.91-0.95 \mathrm{~mm})$ were only those with furrowing or subsoiling when compared to the other six treatments which used attachments promoting greater revolving (rotative hoe, disk harrow, leveling harrow, or moldboard plow). On the other hand, Salvador et al. (2010) compared, in a dystrophic Red Nitosol with $510 \mathrm{~g} \mathrm{~kg}^{-1}$ clay, tilling with disk plow, disk plow + disk harrow, heavy harrow, heavy harrow + disk harrow, and scarifier; the authors concluded that the mean weight diameter was not statistically different, ranging from 5.26 to $8.51 \mathrm{~mm}$.

Pagliai et al. (2004) reported that aggregates were less stable in plowed soils, resulting in a stronger tendency to form crusts than in soils treated with minimum tillage or subsoiling.

In a literature review of 35 papers comparing the tillage systems plowing + harrowing, reduced tillage, or no-tillage, Alvarez \& Steinbach (2009) reported that the change in mean MWD was greater under plowing + harrowing than under reduced tillage or no tillage. On average, the structural instability was reduced by $70 \%$ in the plowing + harrowing tillage in the reviewed studies.

The total number of fruits per plant (TNF), which is an indirect estimate of yield, was statistically equal for the treatments DP + ridge, DP no ridge, DP + SPR and DP+ STA and lowest for the SB treatment (Table 7), showing a disadvantage of this treatment
Table 6. Mean weight diameter (MWD) and geometric mean diameter (GMD) under four tillage systems, 135 days after installing the experiment

\begin{tabular}{lllll}
\hline Treatment & MWD 20 & MWD 40 & GMD 20 & GMD 40 \\
\cline { 2 - 5 } & \multicolumn{5}{c}{$\mathrm{mm}$} \\
$\mathrm{n}$ & $3.32 \mathrm{a}$ & $3.19 \mathrm{ab}$ & $3.23 \mathrm{a}$ & $3.01 \mathrm{ab}$ \\
$\mathrm{SB}$ & $3.30 \mathrm{a}$ & $2.90 \mathrm{~b}$ & $3.22 \mathrm{a}$ & $2.57 \mathrm{~b}$ \\
$\mathrm{DP}+$ SPR & $3.22 \mathrm{a}$ & $3.17 \mathrm{ab}$ & $3.04 \mathrm{a}$ & $2.96 \mathrm{ab}$ \\
DP + STA & $3.32 \mathrm{a}$ & $3.28 \mathrm{a}$ & $3.26 \mathrm{a}$ & $3.18 \mathrm{a}$ \\
Mean & 3.29 & 3.14 & 3.19 & 2.93 \\
CV (\%) & 1.92 & 5.97 & 4.45 & 10.39 \\
\hline
\end{tabular}

Means followed by the same letter are statistically not different by Tukey's test at $5 \%$.

Table 7. Total number of fruits (TNF) per plant 260 days after transplanting in five tillage systems

\begin{tabular}{cc}
\hline Treatment & TNF \\
\hline DP + ridge & $44.8 \mathrm{a}$ \\
DP no ridge & $46.4 \mathrm{a}$ \\
SB & $26.9 \mathrm{~b}$ \\
DP + SPR & $44.2 \mathrm{a}$ \\
DP + STA & $52.3 \mathrm{a}$ \\
Mean & 42.9 \\
CV (\%) & 12.5 \\
\hline
\end{tabular}

Means followed by the same letter in columns are statistically not different by Tukey's test at $5 \%$.

and the ineffectiveness of ridge formation along the plant row to increase papaya yield. Regarding the ridge formation in crops, studies carried out by Pellegrini (2006) and Lawson et al. (2008) reported increased yield in tobacco and soybean, respectively, while Ennin et al. (2009) observed increases in cassava only in the absence of fertilizer.

\section{CONCLUSIONS}

1. All tillage forms tested induced penetration resistance between 2.0 and $3.0 \mathrm{MPa}$ in the area of greatest root concentration of papaya $(0-0.25 \mathrm{~m})$;

2 . There was no statistical difference between treatments in terms of the soil properties bulk density, macroporosity, microporosity, MWD, and GMD.

3. The use of scarification, of reduced tillage with forest subsoiler or ridge formation did not improve the physical properties of the root environment.

4. The use of reduced tillage with a forest subsoiler results in the production of a lower number of fruits per plant compared to the other tillage forms. 


\section{LITERATURE CITED}

ADEKIYA, A.O.; OJENIYI, S.O. \& AGBEDE, T.M. Soil physical and chemical properties and cocoyam yield under different tillage systems in a tropical Alfisol. Exp. Agric., 47:477-488, 2011.

ALVAREZ, R. \& STEINBACH, H.S. A review of the effects of tillage systems on some physical properties, water content, nitrate availability and crops yield in the Argentina Pampas. Soil Till. Res., 104:1-15, 2009.

AMERICAN SOCIETY OF AGRICULTURAL ENGINEERS ASAE. S313.3: Soil cone penetrometer. St. Joseph, 1999.

ARAUJO, M.A.; TORMENA, C.A. \& SILVA, A.P. Propriedades físicas de um Latossolo Vermelho distrófico cultivado e sob mata nativa. R. Bras. Ci. Solo, 28:337-345, 2004.

BLAKE, G.R. \& HARTGE, K.H. Bulk density. In: KLUTE, A., ed. Methods of soil analysis: Physical and mineralogical methods. Madison, ASA-SSSA, 1986. p.363-375.

BORDIN, I.; NEVES, C.S.V.; FRANCIO FILHO, P.; PRETI, E.A. \& CARDOSO, C. Crescimento de milheto e guandu, desempenho de plantas cítricas e propriedades físicas do solo escarificado em um pomar. R. Bras. Ci. Solo, 32:1409$1418,2008$.

BRANDÃO, F.J.C.; REZENDE, J.O.; MAGALHÃES, A.F.; COSTA, J.A.; ZANZARINI, F.V. \& PIMENTEL, U.V. Avaliação de atributos físicos do solo e desenvolvimento da cultivar Tangor Murcote em Latossolo Amarelo coeso sob o efeito da subsolagem. In: CONGRESSSO BRASILEIRO DE CIÊNCIA DO SOLO, 33., Uberlândia, 2011. Resumos... Viçosa, MG, Sociedade Brasileira de Ciência do Solo, 2011. CD-ROM

CAMPOSTRINI, E. \& YAMANISHI, O.K. Influence of mechanical root restriction on gas-exchange of four papaya genotypes. R. Bras. Fisiol. Veg., 13:129-138, 2001.

CARVALHO, J.E.B.; LOPES, L.C.; ARAÚJO, A.M.A.; SOUZA, L.S.; CALDAS, R.C.; DALTRO JÚNIOR, C.A.; CARVALHO, L.L.; OLIVEIRA, A.A.R. \& SANTOS, R.C. Leguminosas e seus efeitos sobre propriedades físicas do solo e produtividade do mamoeiro "Tainung 1". R. Bras. Frutic., 26:335-338. 2004.

CINTRA. F.L.D. Reflexões sobre o efeito dos horizontes coesos no movimento de água no solo e na distribuição do sistema radicular. In: MARTINS, D.S., ed. Papaya Brasil - Mercado e inovações tecnológicas para o mamão. Vitória, Incaper, 2005. $666 \mathrm{p}$

COELHO, E.F.; SANTOS, M.R. \& COELHO FILHO, M.A. Distribuição de raízes do mamoeiro sob diferentes sistemas de irrigação localizada em tabuleiros costeiros. R. Bras. Frutic., 27:175-178, 2005.

CORTEZ, J.W.; ALVES, A.D.S.; MOURA, M.R.D.; OLSZEVSKY, N. \& NAGAHAMA, H.J. Atributos físicos do Argissolo Amarelo do semiárido nordestino sob sistemas de preparo. R. Bras. Ci. Solo, 35:1207-1216, 2011.

COSTA, A.; ALBUQUERQUE, J.A.; MAFRA, A.L. \& SILVA, F.R. Propriedades físicas do solo em sistemas de manejo na integração agricultura-pecuária. R. Bras. Ci. Solo, $33: 235-244,2009$.
COSTA, A.F.S.; COSTA, A.N. \& DESSAUNE FILHO, N. Distribuição do sistema radicular do mamoeiro em solos do Estado do Espírito Santo. In: CONGRESSO BRASILEIRO DE FRUTICULTURA, 15., Poços de Caldas, Lavras: SBF/UFLA/EPAMIG, 1998. 778p.

COSTA, A.F.S.; COSTA, A.N.; SANTOS, F.A.M.; BARRETO, F.C. \& ZUFFO, V.J. Plantio, formação e manejo da cultura. In: MARTINS, D.S. \& COSTA, A.F.S., eds. A cultura do mamoeiro: Tecnologias de produção. Vitória, INCAPER, 2003. 497p.

CRUZ, C.D. Programa Genes: Biometria. Viçosa, MG, Universidade Federal de Viçosa, 2006. 382p.

DEXTER, A.R.; CZYZ, E.A. \& GATE, O.P. A method for prediction of soil penetration resistance. Soil Till. Res., 93:412-419, 2007

EMPRESA BRASILEIRA DE PESQUISAAGROPECUÁRIA - EMBRAPA. Centro Nacional de Pesquisas de Solos. Manual de métodos de análise de solo. 2.ed. Rio de Janeiro, 1997. 212p.

ENNIN, S.A.; OTOO, E. \& TETTEH, F.M. Ridging, a mechanized alternative to mounding for yam and cassava production. West Afr. J. Appl. Ecol., 15:1-8, 2009.

FONTES, P.C.R.; NUNES, J.C.S.; FERNANDES, H.C. \& ARAÚJO, E.F. Características físicas do solo e produtividade da batata dependendo de sistemas de preparo do solo. Hortic. Bras., 25:355-359, 2007.

GRANT, C.A. \& LANFOND, G.P. The effects of tillage systems and crop sequences on soil bulk density and penetration resistance on a clay soil in Southern Saskatchewan. Can. J. Soil Sci., 73:223-232, 1993.

HAMZA, M.A. \& ANDERSON, W.K. Soil compaction in cropping systems. A review of the nature, causes and possible solutions. Soil Till. Res., 82:121-145, 2005.

IMHOFF, S.; SILVA, A.P. \& TORMENA, C.A. Aplicações da curva de resistência no controle da qualidade física de um solo sob pastagem. Pesq. Agropec. Bras., 35:14931500,2000 .

KEMPER, W.D. \& CHEPIL, W.S. Size distribution of aggregates. In: BLACK, C.A.; EVANS, D.D., WHITE, J.L.; ENSMINGER, L.E.; CLARCK, F.E., eds. Methods of soil analysis. Madison, American Society of Agronomy, Soil Science of America, 1965. Part I. p.499-510.

KEMPER, W.D. \& ROSENAU, R.C. Aggregate stability and size distribution. In: BLACK, C.A.; EVANS, D.D., WHITE, J.L.; ENSMINGER, L.E. \& CLARCK, F.E., eds. Methods of soil analysis, Physical and mineralogical methods. Madison, Soil Science Society of America, 1986. Part 1. p.425-442. (Agronomy Monograph, 9)

LAWSON, I.Y.D.; MENSAH, E.A. \& YEBOAH, E.N. Improving the establishment and yield of soybean through planting depth and land preparation methods in Northern Ghana. West Afr. J. Appl. Ecol., 14:1-8, 2008. 
MARLER, T.E.; GEORGE, A.P.; NISSEN, R.J. \& ANDERSSEN, P.C. Miscellaneous tropical fruits. In: SCHAFFER, B. \& ANDERSSEN, P.C., eds. Handbook of environmental physiology of fruit crops: Sub tropical and tropical crops. Boca Raton, CRC Press, 1994. v.2. p.199-224.

MARTINS, D.S. \& COSTA, A.F.S., eds. A cultura do mamoeiro: Tecnologias de produção. Vitória, Incaper, 2003. 497p.

MAZURANA, M.; LEVIEN, R.; MULLER, J. \& CONTE, O. Sistemas de preparo de solo: Alterações na estrutura do solo e rendimento das culturas. R. Bras. Ci. Solo, 35:11971206, 2011.

MELO FILHO, J.F.; OLIVEIRA, A.S.; LOPES, L.C. \& VELLAME, L.M. Análise estatística exploratória e variabilidade da densidade do solo em um perfil de Latossolo Amarelo coeso dos Tabuleiros Costeiros da Bahia. Ci. Agrotec., 30:199-205, 2006.

MEROTTO JUNIOR, A. \& MUNDSTOCK, C.M. Wheat root growth as affected by soil strength. R. Bras. Ci. Solo, 23:197-202, 1999.

MINATEL, A.L.G.; ANDRIOLI, I.; CENTURION, J.F. \& NATALE, W. Efeitos da subsolagem e da adubação verde nas propriedades físicas do solo em pomar de citrus. Eng. Agríc., 26:86-95, 2006.

NACIF, P.G.S. Efeito da subsolagem em propriedades físicohídricas de um Latossolo Amarelo álico coeso representativo do Recôncavo Baiano. Viçosa, MG, Universidade Federal de Viçosa, 1994. 75p. (Dissertação de Mestrado)

PAGLIAI, M.; VIGNOZZI, N. \& PELLEGRINI, S. Soil structure and the effect of management practices. Soil Till. Res., 79:131-143, 2004.

PAIVA, A.Q.; SOUZA, L.S.; RIBEIRO, A.C. \& COSTA, L.M. Propriedades físico-hídricas de solos de uma topossequência de Tabuleiros do estado da Bahia. Pesq. Agropec. Bras., 35:2295-2302, 2000.

PELLEGRINI, A. Sistemas de cultivo da cultura do fumo com ênfase nas práticas de manejo e conservação do solo. Santa Maria, Universidade Federal de Santa Maria, 2006. 90p. (Dissertação de Mestrado)

RIBEIRO, K.A.; OLIVEIRA, T.S.; MENDONÇA, E.S.; XAVIER, F.A.S.; MAIA, S.M.F. \& SOUSA, H.H.F. Qualidade do solo na cultura do cajueiro anão precoce cultivado sob diferentes sistemas de manejo. R. Bras. Ci. Solo, 31:341$351,2007$.

ROSA, D.P.; REICHERT, J.M.; MENTGES, M.I.; BARROS, C.A.P.; REINERT, D.J. \& VIEIRA, D.A. Cultivo mínimo: Efeito da compactação e deformação abaixo da atuação da ponteira do subsolador. R. Bras. Eng. Agríc. Amb., 15:1199-1205, 2011.
SALVADOR, N.; MION, R.L.; BENEZ, S.H. \& VILIOTTI, C.A. Estudo da demanda energética e desagregação do solo em diferentes sequências operacionais de preparo periódico. R. Ci. Agron., 41:231-236, 2010.

SANTANA, M.B.; SOUZA, L.S.; SOUZA, L.D. \& FONTES, L.E.F. Atributos físicos do solo e distribuição do sistema radicular de citrus como indicadores de horizontes coesos em dois solos de Tabuleiros Costeiros do estado da Bahia. R. Bras. Ci. Solo, 30:1-12, 2006.

SANTOS, D.M.B. Efeito da subsolagem mecânica sobre a estrutura de um solo de Tabuleiro (Latossolo Amarelo álico coeso) no município de Cruz das Almas - Bahia (caso 2). Salvador, Universidade Federal da Bahia, 1992. 87p. (Dissertação de Mestrado)

SCHAEFER, C.E.G.R.; SOUZA, C.M.; VALLEJOS, M.F.J.; VIANA, J.H.M.; GALVÃO, J.C.C. \& RIBEIRO, L.M. Características da porosidade de um Argissolo VermelhoAmarelo submetido a diferentes sistemas de preparo de solo. R. Bras. de Ci. Solo, 25:765-769, 2001.

SENRA, A.F.; LOUZADA, R.O.; VITORINO, A.C.T.; SOUZA, C.M.A. \& VICTOR, D.M. Resistência à penetração em Latossolo Vermelho sob diferentes sistemas de uso e manejo do solo. R. Ci. Tecn. Agropec., 16:31-36, 2007.

SILVA, F.C.C. Preparo do solo e operações de plantio. Inf. Agropec., 134:24-26, 1986.

STOLF, R. Teoria e teste experimental de fórmulas de transformação dos dados de penetrômetro de impacto em resistência do solo. R. Bras. Ci. Solo, 15:229-235, 1991.

STOLF, R.; FERNANDES, J. \& FURLANI NETO, V.L. Penetrômetro de impacto IAA/PLANALSUCAR-STOLF: Recomendações para seu uso. STAB, 3:18-23,1983.

TAVARES FILHO, J.; BARBOSA, G.M.C.; GUIMARÃES, M.F. \& FONSECA, I.C.B. Resistência do solo à penetração e desenvolvimento do sistema radicular do milho (Zea mays L.) sob diferentes sistemas de manejo em um Latossolo Roxo. R. Bras. Ci. Solo, 25:725-730, 2001.

TAYLOR, S.A. \& ASCHROFT, G.L. Physical edaphology - The physics of irrigated and non irrigated soils. San Francisco, W.H. Freeman, 1972. 532p.

UNGER, P.W. \& KASPAR, T. Soil compaction and root growth: A review. Agron. J., 86:759-766, 1994.

XU, X.; NIEBER, J.L. \& GUPTA, S.C. Compaction effect on the gas diffusion coefficient in soils. Soil Sci. Soc. Am. J., 56:1743-1750, 1992.

YODER, R.E. A direct method of aggregate analysis of soils and a study of the physical nature of erosion losses. J. Am. Soc. Agron., 28:337-351, 1936. 